DOI: 10.17707/AgricultForest.64.1.04

\author{
Katarzyna TAJCHMAN, \\ Marek BOGDASZEWSKI, Edyta KOWALCZUK-VASILEV, \\ Żaneta STEINER-BOGDASZEWSKA, Pawet BOGDASZEWSKI ${ }^{1}$
}

\title{
MINERAL CONCENTRATIONS IN THE PLASMA OF YOUNG FARMED FALLOW DEER (Dama dama) IN RELATION TO THE FEEDING SYSTEM
}

\begin{abstract}
SUMMARY
Ruminant breeders, who strive to feed their animals properly, focus their attention on three components of diet: metabolic energy, total protein and raw fibre. Properly balanced nutrition should take into account another element, i.e. the proper level of mineral-vitamin compounds.

The paper shows the effects of nutrition on the content of micro- and macro-elements in the blood of farmed fallow deer reared in two systems. Male calves constituted the main study group. All the animals had constant access to water and hay. One of the groups of the animals kept in a special rearing house received a complementary mineral feed mixture for calves "Cielak plus 2.5\%" produced by LNB (Cargill, Poland); the administration followed manufacturer's recommendations. Additionally, the feed contained fodder composed of $70 \%$ of crushed oats, $15 \%$ of the "universal rapeseed concentrate" (producer: Eko-pasz, Mońki, Poland) containing 33\% of crude protein, and $15 \%$ of the "universal soybean concentrate” (producer: Eko-pasz, Mońki, Poland) with 45\% of crude protein. The second group was reared in a free-range system outside the calf-shed and was fed roughage feeds ad libitum.

The aim of this study was to determine the selected minerals in the plasma of young farmed fallow deer. The blood was collected at slaughter, which is a natural element in the farm rearing technology. Plasma P, Ca, Mg, Zn, Fe, and $\mathrm{Cu}$ levels were determined. Specific reference intervals are needed for each animal species for appropriate interpretation of haematological and serum biochemical results. Serum biochemical parameters, such as phosphorus, calcium, magnesium, zinc, copper and iron content, were determined using reagent kits (BioMaxima, Lublin, Poland), according to manufacturer's protocol and a random access biochemical analyser Metrolab 2300 GL (Metrolab SA, Buenos Aires, Argentine). The preliminary results confirm the beneficial effect

\footnotetext{
${ }^{1}$ Katarzyna Tajchman (corresponding author: katarzyna.tajchman@up.lublin.pl), Department of Ethology and Animal Welfare, University of Life Sciences in Lublin, POLAND; Marek Bogdaszewski, Żaneta Steiner-Bogdaszewska, Paweł Bogdaszewski, Institute of Parasitology PAN, Researche Station in Kosewo Górne, POLAND; Edyta Kowalczuk-Vasilev, Institute of Animal Nutrition and Bromatology, University of Life Sciences in Lublin, POLAND

Paper presented at the $8^{\text {th }}$ International Scientific Agricultural Symposium "AGROSYM 2017".

Notes: The authors declare that they have no conflicts of interest. Authorship Form signed online.
} 
of feeding young animals diets containing higher protein contents and mineral mixes.

Keywords: Dama dama, nutrition, micro- and macro-elements.

\section{INTRODUCTION}

In Poland, Cervidae breeding was made possible by virtue of the Act of 29 June 2007 on organisation of breeding and reproduction of farmed animals (Journal of Laws 2007 no. 133, item 921). As specified in chapter 1, Art. 2, Par. $1 \mathrm{c}$ ), Cervidae species such as the red deer (Cervus elaphus), sika deer (Cervus nippon), and fallow deer (Dama dama) reared in farm conditions for production of meat and pelts are classified as livestock animals if they originate from closed or free-range rearing and breeding systems. In other countries, other cervid rearing and breeding objectives are additionally implemented, i.e. panty production (antlers in a growth form) and the use of animals in tourism and agritourism (Janiszewski et al., 2014, Dmuchowski 2003).

To provide their animals with proper nutrition, breeders focus on three nutritional components of feed, i.e. metabolic energy, total protein, and raw fibre. Properly balanced diets should provide an appropriate level of mineral-vitamin compounds as well. Cervidae, including the fallow deer, are characterised by special nutritional requirements and are particularly susceptible to mineral compound deficiencies due to the increased demand for minerals during the period of development and ossification of antlers. This is a special time during the rearing period, as osteoporosis of the skeletal system may then develop, leading to weakening of the organism.

In Cervidae, the quality of the first antler is an indicator of the ontogenetic quality and a phenotypic trait that can reflect the quality of food (Gaspar-Lopez et al., 2008). In the farm breeding practice, there is a possibility and, hence, a necessity to offer animals appropriate living conditions directly after birth and to provide properly balanced nutrition to hinds and calves immediately after weaning.

\section{MATERIAL AND METHODS}

The research was carried out at the Research Station of the Institute of Parasitology, Polish Academy of Sciences, Kosewo Górne, Poland, in 2014-2016. Eighteen male calves constituted the main study group. All animals had constant ad libitum access to water and hay. The fallow deer were divided into two groups of equal size. One group was kept in a special rearing building and the other one was reared in a free-range system.

Each animal received $260 \mathrm{~g}$ of a mixture per day with the following composition: $70 \%$ of crushed oats in $15 \%$ of "universal rapeseed concentrate" (producer: Eko-pasz, Mońki, Poland) containing 33\% of crude protein, and in $15 \%$ of "universal soybean concentrate" (producer: Eko-pasz, Mońki, Poland) with $45 \%$ crude protein content. Additionally, the diet was supplemented with a complementary mineral feed mixture for calves "Cielak plus 2,5\%" (produced by LNB, Cargill, Polska) in accordance with manufacturer's recommendations. Our 
unpublished observations revealed homogeneous feed intake by the animals, although the exact level of feed intake by each animal was not determined.

The effects of intensive nutrition with the use of the diet described above on the blood levels of micro- and macro-elements in the farmed fallow deer reared in two different systems were analysed. The aim of this study was to determine selected minerals in plasma in young farmed fallow deer. Blood was collected at slaughter in the second year of animals' age (August 2016). Plasma P, $\mathrm{Ca}, \mathrm{Mg}, \mathrm{Zn}, \mathrm{Fe}$, and $\mathrm{Cu}$ levels were determined. Specific reference intervals are needed for each animal species for appropriate interpretation of haematological and serum biochemical results. Serum biochemical parameters, such as phosphorus, calcium, magnesium, zinc, copper and iron content, were determined using reagent kits (BioMaxima, Lublin, Poland) according to the manufacturer's protocol and a random access biochemical analyser Metrolab 2300 GL (Metrolab SA, Buenos Aires, Argentine).

The animal body weight was measured at the beginning (November 2014) and end (May 2015) of the study period and in August 2016. The measurements were carried out with the use of a set of MP 800 sensors coupled with a Tru-test DR 3000 weight reader. As declared by the manufacturer, the accuracy of this set is $+/-1 \%$ and the minimum resolution is $0,1 \mathrm{~kg}$. To obtain additional information about the ontogeny of the young fallow deer males, the growing antlers with the pedicle (at the skull base) were measured twice. The measurements were done at the age of 11 and 26 months using a tape measure and the mean values of the measurement of both beams were noted (in each case, the differences in the length did not exceed $1 \mathrm{~cm}$ ).

All the data were analysed with Statistica software ver. 10 (StatSoft, Tulsa, OK, US, 2011). The normality was assessed using the Kolmogorov-Smirnov test, and Levene's homogeneity of variance test was applied to examine the equality of variances. The data obtained were analysed with the ANOVA method using one-way analysis of variance and calculating the mean values for the treatments, standard deviation (SD), and the standard error of the mean (SEM). The means were compared using Tukey's test. All statements of significance were based on a probability $\mathrm{P} \leq 0.05$ and $\mathrm{P}$ values between 0.05 and 0.1 were considered as a trend.

\section{RESULTS AND DISCUSSION}

A positive effect of the mineral supplementation before the second year of age of the fallow deer was observed. Animals receiving the supplemented diet exhibited increased plasma levels of the analysed minerals $(\mathrm{Zn}, \mathrm{P}, \mathrm{Mg}, \mathrm{Cu}, \mathrm{Ca}$, $\mathrm{Fe}$ ). Higher contents of some mineral compounds were found in the animals kept in the calf-shed. The values were higher on average by 5,46 umol/l, 2,82 umol/l, and $0,23 \mathrm{mmol} / \mathrm{l}$ in the case of iron, zinc, and phosphorus, respectively. The levels of magnesium, calcium, and copper did not differ substantially and were slightly higher in animals receiving the additional supplementation. Significant statistical differences in the level of calcium were noted between the groups. Its mean content in the control group was $2,3 \mathrm{mmol} / \mathrm{l}+0,12$, and a higher value, i.e. 
$2,42 \mathrm{mmol} / \mathrm{l}+0,12$, was determined in the experimental group, which indicates a high demand of fallow deer for calcium as well as magnesium, phosphorus, and copper during the development and mineralisation of antlers (Table 1, Table 2).

Table1. Comparison of content of selected micro- and macro elements (Zn, P, $\mathrm{Mg}, \mathrm{Cu}, \mathrm{Ca}, \mathrm{Fe}$ ) in fallow deer plasma.

\begin{tabular}{|c|c|c|c|c|c|c|c|}
\hline & $\begin{array}{l}\text { No. } \\
\text { animal }\end{array}$ & $\begin{array}{l}\mathrm{Zn} \\
\mathrm{umol} / \mathrm{l}\end{array}$ & $\begin{array}{l}\mathrm{P} \\
\mathrm{mmol} / \mathrm{l}\end{array}$ & $\begin{array}{l}\mathrm{Mg} \\
\mathrm{mmol} / \mathrm{l}\end{array}$ & $\begin{array}{l}\mathrm{Cu} \\
\mathrm{umol} / \mathrm{l}\end{array}$ & $\begin{array}{l}\mathrm{Ca} \\
\mathrm{mmol} / \mathrm{l}\end{array}$ & $\begin{array}{l}\mathrm{Fe} \\
\text { umol/l }\end{array}$ \\
\hline \multirow{9}{*}{ control group } & 1 & 9,60 & 2,20 & 0,85 & 13,80 & 2,47 & 28,34 \\
\hline & 2 & 8,26 & 1,67 & 0,78 & 14,94 & 2,18 & 21,52 \\
\hline & 3 & 6,19 & 1,71 & 0,74 & 15,61 & 2,23 & 16,22 \\
\hline & 4 & 7,74 & 1,52 & 0,80 & 13,45 & 2,35 & 19,66 \\
\hline & 5 & 9,06 & 1,50 & 0,81 & 15,70 & 2,42 & 45,03 \\
\hline & 6 & 6,34 & 1,69 & 0,80 & 14,81 & 2,21 & 22,30 \\
\hline & 7 & 9,97 & 2,33 & 0,87 & 15,10 & 2,45 & 26,10 \\
\hline & 8 & 8,20 & 1,77 & 0,69 & 14,44 & 2,19 & 27,20 \\
\hline & 9 & 8,35 & 1,65 & 0,87 & 13,34 & 2,22 & 26,60 \\
\hline \multicolumn{2}{|l|}{ average } & 8,19 & 1,78 & 0,80 & 14,57 & 2,30 & 25,88 \\
\hline \multirow{9}{*}{$\begin{array}{l}\text { experimental } \\
\text { group }\end{array}$} & 10 & 6,58 & 1,86 & 0,98 & 13,01 & 2,40 & 32,67 \\
\hline & 11 & 8,19 & 2,16 & 0,93 & 16,10 & 2,40 & 34,59 \\
\hline & 12 & 11,04 & 1,77 & 0,85 & 15,63 & 2,45 & 30,75 \\
\hline & 13 & 5,95 & 2,16 & 0,82 & 12,87 & 2,28 & 27,02 \\
\hline & 14 & 15,99 & \begin{tabular}{|l|}
1,62 \\
\end{tabular} & 0,73 & 14,70 & 2,39 & 17,20 \\
\hline & 15 & 17,84 & 2,37 & 0,90 & \begin{tabular}{|l|}
13,71 \\
\end{tabular} & 2,70 & 33,02 \\
\hline & 16 & 14,68 & 2,19 & 0,82 & 18,56 & 2,43 & 46,21 \\
\hline & 17 & 11,28 & 1,90 & 0,80 & 14,75 & 2,32 & 35,60 \\
\hline & 18 & 7,53 & 2,05 & 0,88 & 14,20 & 2,44 & 25,02 \\
\hline \multicolumn{2}{|l|}{$\begin{array}{l}\text { average } \\
\end{array}$} & 11,01 & 2,01 & 0,86 & \begin{tabular}{|l|}
14,84 \\
\end{tabular} & 2,42 & 31,34 \\
\hline
\end{tabular}

Besides the higher levels of the minerals in the plasma of the farmed fallow deer, a positive effect of the mineral supplementation on the growth of the first antlers was shown. The antlers were on average by ca. $2 \mathrm{~cm}$ longer in the animals kept in the calf-shed during the first measurements and by 3,6 cm longer in the subsequent year. Additionally, more uniform growth of antlers was observed in the animals receiving the supplemented diet. 
Table 2. Analysis of the variation of micro- and macro element content in plasma between groups with standard deviation of probability at the level $\mathrm{P} \leq 0,05$.

\begin{tabular}{|c|c|c|c|c|}
\hline Group & $\begin{array}{c}\text { control } \\
\text { mean } \pm S D\end{array}$ & experimental mean $\pm S D$ & P value & SEM \\
\hline $\mathrm{Zn} \mathrm{umol} / \mathrm{l}$ & $8.19 \pm 1.30$ & $11.00 \pm 4.33$ & 0.080 & 0.808 \\
\hline $\mathrm{P} \mathrm{mmol} / \mathrm{l}$ & $1.78 \pm 0.29$ & $2.01 \pm 0.24$ & 0.088 & 0.066 \\
\hline $\mathrm{Mg} \mathrm{mmol} / \mathrm{l}$ & $0.80 \pm 0.06$ & $0.86 \pm 0.08$ & 0.101 & 0.017 \\
\hline $\mathrm{Cu} \mathrm{umol} / \mathrm{l}$ & $14.58 \pm 0.88$ & $14.84 \pm 1.77$ & 0.698 & 0.321 \\
\hline $\mathrm{Ca} \mathrm{mmol} / \mathrm{l}$ & $2.30^{\mathrm{b}} \pm 0.12$ & $2.42^{\mathrm{a}} \pm 0.12$ & 0.046 & 0.031 \\
\hline $\mathrm{Fe} \mathrm{umol} / \mathrm{l}$ & $25.88 \pm 8.21$ & $31.34 \pm 8.01$ & 0.173 & 1.969 \\
\hline
\end{tabular}

During the investigations, the animals were weighed. The fallow deer from the experimental group exhibited higher body weight (by approx. 4,5 kg) at the age of 11 months and weighed on average ca. 32,3 kg. In turn, the control animals weighed on average 30,2 kg. After 26 months, more equal body weight gains were noted in both groups, which may be associated with the identical diets provided to the animals in the two groups in the second year. The mean body weight of the animals from the two groups differed only by $0,3 \mathrm{~kg}$ in that period. The animals from the group fed with the supplemented diet reached a body weight of $42,6 \mathrm{~kg}$ (Table 3).

The analysis of changes in the biometric parameters revealed a significant difference between the control group and the group of animals fed with the supplemented diet. After 11 months, the mean body weight of the animals from the former group was $28,5 \mathrm{~kg}+2,38$, while the animals from the latter group were characterised by higher values, i.e. 32,3 kg + 4,08 (Table 4). Significant correlations between the groups were shown in the animal body weight gain after 26 months. The groups differed between each other, i.e. the body weight gain was $18,1 \mathrm{~kg}+2.88$ in the control group and $14,9 \mathrm{~kg}+2,77$ in the experimental group. There were also significant correlations in terms of the antler growth values between the groups in both measurement periods. The mean antler length after 11 months was $2,5 \mathrm{~cm}+0,81$ in the control group and 4,5 $\mathrm{cm}+2,28$ in the experimental group. After 26 months, the mean antler length was $9,7 \mathrm{~kg}+2,26$, whereas a higher value, i.e. $13,3 \mathrm{~kg}+2,99$, was noted in the experimental group (Table 4).

The results of this study are comparable to those presented in the literature. In their investigations of the red deer, Peinado et al. (1999) reported a plasma calcium concentration of 2,24 mmol/l and an elevated level of phosphorus, i.e. $3,87 \mathrm{mmol} / \mathrm{l}$. The concentrations of calcium, phosphorus, and magnesium determined by Kuba (2014) (mean values: Ca- 1,96 mmol/l, P- 1,83 mmol/l, Mg$0,6 \mathrm{~mol} / \mathrm{l}$ ) were lower than the values in the non-supplemented fallow deer kept in the free-range system (Ca- 2,30 mmol/l, P-1,76 mmol/l, Mg- 0,8 mmol/l). This may be associated with the better quality of the standard diets provided in the farm where the present study was carried out. 
Table 3. Body weight and length of antler at fallow deer in the sixth, eleventh, and $26^{\text {th }}$ month of life.

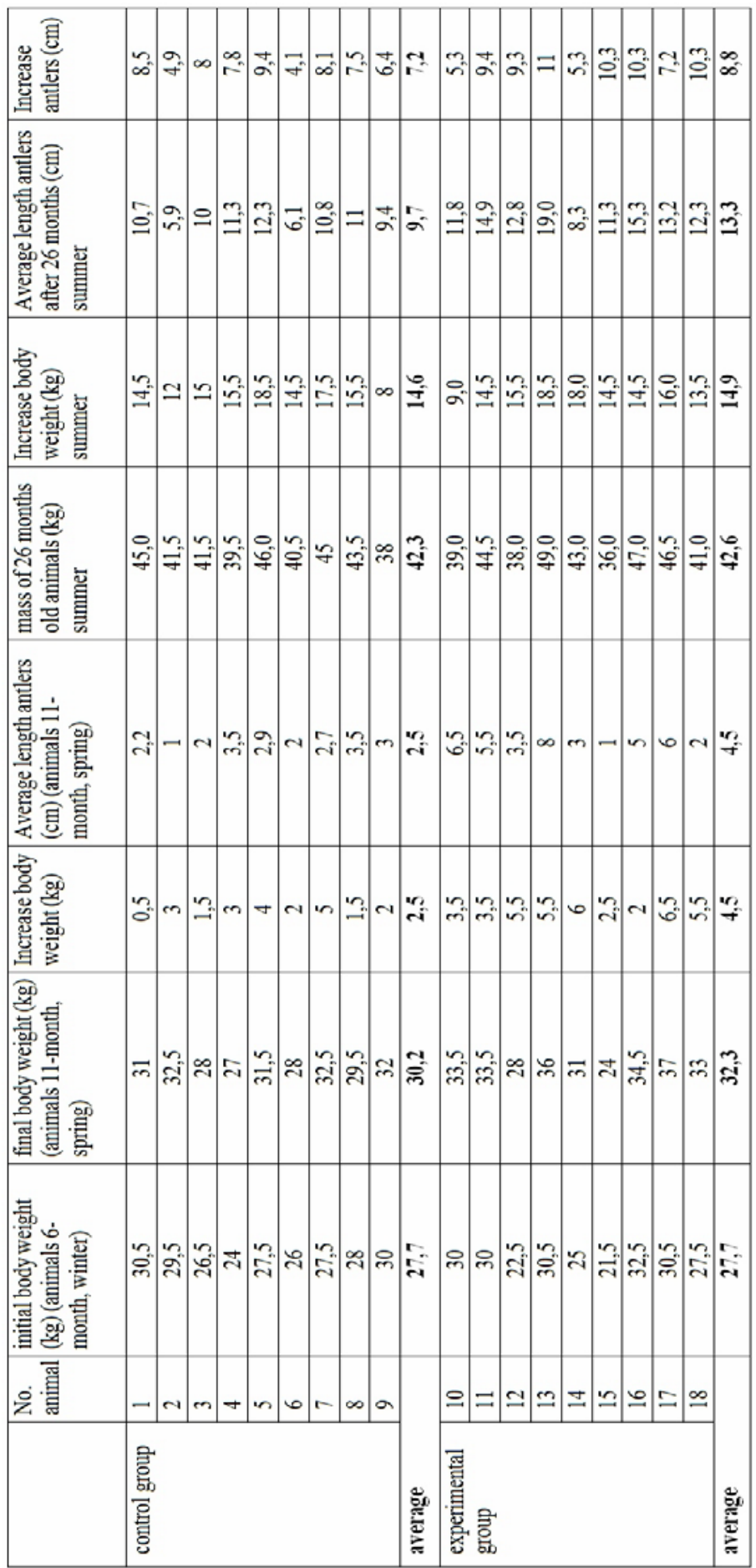


Table 4. Analysis of body weight variance and antler length between fallow deer groups with a standard deviation of probability at the $\mathrm{P} \leq 0,05$.

\begin{tabular}{|l|c|c|c|c|}
\hline \multicolumn{1}{|c|}{ Group } & $\begin{array}{c}\text { control } \\
\text { mean } \pm S D\end{array}$ & $\begin{array}{c}\text { experimental } \\
\text { mean } \pm S D\end{array}$ & $\begin{array}{c}\text { P } \\
\text { value }\end{array}$ & SEM \\
\hline $\begin{array}{l}\text { Initial body weight (kg) } \\
\text { (animals 6-month) }\end{array}$ & $27.72 \pm 2.08$ & $27.77 \pm 3.91$ & 0.970 & 0,715 \\
\hline $\begin{array}{l}\text { Final body weight (kg) } \\
\text { (animals 11-month) }\end{array}$ & $30.22 \pm 2.14$ & $32.28 \pm 4.08$ & 0.199 & 0,785 \\
\hline $\begin{array}{l}\text { Increase body weight } \\
\text { (kg) }\end{array}$ & $2.50^{\mathrm{b}} \pm 1.39$ & $4.50^{\mathrm{a}} \pm 1.64$ & 0.013 & 0,424 \\
\hline $\begin{array}{l}\text { Average length antlers (cm) } \\
\text { (animals 11-month) }\end{array}$ & $2.5^{\mathrm{b}} \pm 0.81$ & $4.5^{\mathrm{a}} \pm 2.28$ & 0.027 & 0,458 \\
\hline $\begin{array}{l}\text { mass of 26 months old } \\
\text { animals (kg) }\end{array}$ & $42.28 \pm 2.75$ & $42.67 \pm 4.47$ & 0.827 & 0,849 \\
\hline $\begin{array}{l}\text { Increase body weight } \\
\text { (kg) }\end{array}$ & $14.56 \pm 3.08$ & $14.89 \pm 2.77$ & 0.812 & 0,671 \\
\hline $\begin{array}{l}\text { Average length } \\
\text { antlers after 26 months (cm) }\end{array}$ & $9.7^{\mathrm{b}} \pm 2.26$ & $13.3^{\mathrm{a}} \pm 2.99$ & 0.013 & 0,739 \\
\hline $\begin{array}{l}\text { Increase antlers } \\
\text { (cm) }\end{array}$ & $7.2 \pm 1.73$ & $8.8 \pm 2.21$ & 0.124 & 0,490 \\
\hline
\end{tabular}

Fallow deer plasma was sampled in summer, a year after the supplementation. In this period, animals should not suffer from nutritional deficiencies due to the good quality of pastures. Yet, relatively large differences in the plasma content of micro- and macroelements were observed between the supplemented and non-supplemented animal groups. This indicates a low level of compensation of nutritional deficiencies arising at a younger age, in particular during the weaning period, when animals should receive special care. The composition of the hinds' milk itself has a significant effect on Cervidae. It has been shown in the Iberian red deer (Cervus elaphus hispanicus) that the composition of milk exerts an impact on the morphological traits of the first antler, in particular its length. The length of the antler was measured from the value of 2,5 cm to the end of its growth. Between weeks 2 and 8 , the gain was inconsiderable, i.e. from $0,5-3,0 \mathrm{~cm}$ to $1-19,0 \mathrm{~cm}$. The greatest increase in the length, i.e. 10,0-55,0 cm, was noted between week 8 and 20. In the final period of growth between week 20 and 28, the antler length was 21,5-55,5 cm. In comparison with wild-living animals in which the length of the first antler can be highly variable in some individuals and range from $15 \mathrm{~cm}$ to $60 \mathrm{~cm}$, it can be observed that the value is stable in most individuals provided with adequate nutrition and reaches on average 38,3 cm (Gaspar-Lopez et al., 2008). This thesis is also confirmed by the results of the present study carried out on farmed fallow deer. 
The issue of appropriate feeding is especially important in Cervidae calves, whose survival of the first winter depends on proper body weight (Fenessy et al., 1991). Studies have shown that early growth in young animals, especially in males, is highly important, as it determines some antler traits (weight and length) in adult deer and influences future reproductive success (Gómez et al., 2006, 2008, Landete-Castillejos et al., 2007 a).

In favourable environmental conditions ensuring good health status of animals, the young red deer can begin puberty up to two months earlier (at the age of 14-16 months) (Asher and Cox, 2013). On the other hand, adverse conditions can considerably delay this moment even until the third or fourth autumn after birth. This boundary is unstable and is reached when animals achieve $65-70 \%$ of the target weight, which is an effect of the availability and quality of feed (Asher et al., 2011, Cilulko, 2011).

Most studies on cervid nutrition conducted so far have mainly been focused on the content and quality of proteins and energy compounds. However, the role of micro- and macroelements, in particular calcium, phosphorus, and magnesium, is highly important. These mineral compounds build up the antler bone mass in Cervidae (Landete-Castillejos et al., 2007 b). Special attention should be paid to the high demand of Cervidae for calcium, which is supplied with feed only in $25-40 \%$, while the other amount originates from the pool deposited in their bones (Muir et al., 1987).

The effect of supplementation of diets in farmed Iberian red deer (Cervus elaphus hispanicus) has been investigated. For three years post weaning, the animals were administered higher amounts of mineral compounds, i.e. Ca, P, Mg, $\mathrm{K}, \mathrm{Na}, \mathrm{S}, \mathrm{Cu}, \mathrm{Fe}, \mathrm{Mn}, \mathrm{Se}, \mathrm{Zn}, \mathrm{B}$, and Sr, in a complementary diet. The higher availability of the micronutrients in the feed was reflected in the chemical composition and mechanical properties of bones. A significant difference in biometric parameters was shown between the control group and animals receiving the supplemented diet. The mean body weight of animals from the former group was 83,6 $\mathrm{kg}+1.6$; in the latter group, the value was higher, i.e. 90,1 $\mathrm{kg}+1,4$. Similarly, the KFI value differed between the groups and was $65,42 \mathrm{~kg}$ $+9,9 \%$ and $131,26 \mathrm{~kg}+13,7 \%$, respectively. No differences in the chest circumference, body length, femur length, cortical thickness, or mechanical properties were found (Olguin et al., 2013).

\section{CONCLUSIONS}

The results have demonstrated a beneficial effect of mineral supplementation on the weight and form of antlers and the ontogenic quality of the animals. A significant correlation was observed in the case of calcium, whose plasma content was higher in the experimental group and which appeared to be the most vital macroelement for the structure of antlers. The other micro- and macroelements $(\mathrm{Zn}, \mathrm{P}, \mathrm{Mg}, \mathrm{Cu})$ also play an important role in farmed fallow deer. Their plasma content was also higher in the supplemented group. Therefore, special attention should be placed on mineral-vitamin supplementation during the 
calf wintering period, as it influences the subsequent years of animal life and contributes to achievement of appropriate weight and more uniform growth of antlers.

\section{REFERENCES}

Asher G.W., Archer J.A., Ward J.F., Littlejohn R.P. (2011). Effect of melatonin implants on the incidence and timing of puberty in female red deer (Cervus elaphus). Anim. Reprod. Sci. vol. 123 (3-4), pp. 202-209.

Asher G.W., Cox N. (2013). The relationship between body-mass and puberty in young red deer (Cervus elaphus) hinds: evidence of early-life effects on permissive liveweight thresholds. Anim. Reprod. Sci. vol. 143 (1-4), pp. 79-84.

Borys B., Bogdaszewska Z., Bogdaszewski M. (2012). Dynamic growth of farmed fallow deer and red deer farms in Poland. (Dynamiczny wzrost fermowej hodowli danieli i jeleni w Polsce). Wiad. Zootech. vol. 1, pp. 33-44.

Ceacero F. (2010). Mineral supplementation and mineral diet selection in Iberian red deer (Cervus elaphus). Doctoral thesis. Universidad de Castilla-La Mancha, Albacete, Spain.

Cilulko J. (2011). Cervinia breeding. Vol. 1. Selected aspects of reproductive biology. (Rozród jeleniowatych. Cz. 1. Wybrane aspekty biologii rozrodu). Prz. Hod. vol. 5, pp. 26-31.

Dmuchowski B., Dmuchowska T., Gawrysiak P., Demiaszkiewicz A.W., Guślakow L. (2003). Basics of cervid farm. Training workshops. (Podstawy hodowli fermowej jeleniowatych. Warsztaty szkoleniowe). Wyd. Stacja Badawcza Instytutu Parazytologii PAN, Kosewo Górne.

Fennessy P.F., Thomson J.M., Suttie J.M. (1991). Season and growth strategy in red deer. Evolutionary implications and nutritional management. In: Wildlife production: conservation and sustainable development. University of Alaska, Fairbanks.

Gaspar-López E., García A.J., Landete-Castillejos T., Carrión D., Estévez J.A., Gallego L., 2008. Growth of the first antler in Iberian red deer (Cervus elaphus hispanicus). Eur. J. Wildl. Res. vol. 54 (1), pp. 1-5.

Gómez J.A., Landete-Castillejos T., García A.J., Sánchez P.J., Estévez J.A., Gallego L. (2006). Effect of lactation on mineral composition of first antler in Iberian red deer (Cervus elaphus hispanicus). Livest. Sci. vol. 105 (1), pp. 27-34.

Gómez J.A., Landete-Castillejos T., García A.J., Gaspar-López E., Estevez J.A., Gallego L. (2008). Lactation growth influences mineral composition of first antler in Iberian red deer Cervus elaphus hispanicus. Wildl. Biol. vol. 14 (3), pp. 331-338.

Janiszewski P., Bogdaszewska Z., Bogdaszewski M., Bogdaszewski P., Cilulko- Dołęga J., Nasiadka P., Steiner Ż. (2014). Cattery and breeding of deer. (Chów i Hodowla Fermowa Jeleniowatych). Wydawnictwo Uniwersytetu Warmińsko-Mazurskiego, Olsztyn.

Kuba J. 2014. Analysis of changes in the concentration of Ca, P and $\mathrm{Mg}$ in blood serum of red deer (Cervus elaphus) immature males in farm breeding. Acta Sci. Pol., Zootechnica 13 (2): 31-40

Landete-Castillejos T., Currey J.D., Estévez J.A., Gaspar-López E., García A.J., Gallego L. (2007 a). Influence of physiological effort of growth and chemical composition on antler bone mechanicals properties. Bone vol. 41 (5), pp. 794-803.

Landete-Castillejos T., Garcia A., Gallego L. (2007 b). Body weight, early growth and antler size influence antler bone mineral composition of Iberian Red Deer (Cervus elaphus hispanicus). Bone vol. 40 (1), pp. 230-235. 
Muir P.D., Sykes A.R., Barrell G.K. (1987). Calcium metabolism in red deer (Cervus elaphus) offered herbages during antlerogenesis: kinetic and stable balance studies. J. Agric. Sci. Camb. vol. 109, pp. 357-364.

Nazaruk M., Jankowska-Huflejt H., Wróbel B. (2009). Evaluation of feed value of grassland pasture in tested ecological farms. Water - Environment - Rural Areas (Ocena wartości pokarmowej pasz z trwałych użytków zielonych w badanych gospodarstwach ekologicznych. Woda - Środowisko - Obszary Wiejskie) vol. 9 (1), pp. 61-76.

Olguin C.A., Landete-Castillejos T., Ceacero F., Garcia A.J., Gallego L. (2013). Effects of Feed Supplementation on Mineral Composition, Mechanical Properties and Structure in Femurs of Iberian Red Deer Hinds (Cervus elaphus hispanicus). PLoS One. vol. 8(6): e65461.

Peinado V.I., Celdran J.F., Palomequ J. (1999). Blood Biochemistry Values in Some Wild Ruminants 